\title{
Kematangan Karir Mahasiswa Prodi Ekonomi Dalam Pemilihan Karir
}

\author{
Mhd Subhan ${ }^{1}$, Hasgimianti ${ }^{2}$, Wardani Purnama Sari ${ }^{3}$, Salleh Amat ${ }^{4}$, Abu Yazid Abu Bakar ${ }^{5}$ \\ 1,2,3 Universitas Islam Negeri Sultan Syarif Kasim Riau \\ ${ }^{4,5}$ Universiti Kebangsaan Malaysia \\ e-mail: mhd.subhan@uin-suska.ac.id
}

\begin{abstract}
ABSTRAK. Penelitian ini bertujuan untuk melihat gambaran kematangan karir mahasiswa prodi ekonomi dalam pemilihan karir. Subjek penelitian ini berjumlah 40 orang mahasiswa. Alat pengumpulan data menggunakan angket dan skor yang digunakan untuk analisis data. Variabel ini memiliki 2 sub domain yaitu domain sikap terdiri 5 indikator dan domain keterampilan terdiri dari 5 indikator juga. Hasil penelitian menunjukkan kematangan karir mahasiswa prodi ekonomi dalam pemilihan karir berada pada tahap yang rendah. Terdapat perbedaan kematangan karir antara lakilaki dan perempuan yang lebih dominan kematangan karir perempuan lebih tinggi berbanding kematangan karir laki-laki. Dengan demikian, hasil penelitian ini memberikan hasil yang bermakna yang dapat menjadi rujukan bagi seluruh stake holder dalam pengembangan mahasiswa menjadi mandiri dan cemerlang di masa depan. Saran bagi penelitian selanjutnya sangat penting dijalankan bagi seluruh mahasiswa supaya dapat mengetahui kematangan karir mahasiswa secara komprehensif.
\end{abstract}

Kata kunci: Kematangan Karir, Mahasiswa, Pemilihan Karir.

\section{PENDAHULUAN}

Pada era revolusi industri 4.0 ini sangat memberi dampak bagi seluruh generasi dalam pemilihan karir. Teknologi sangat memberi peranan yang penting bagi mahasiswa yang akan menghadapi dunia pekerjaan. Ditambah pekerjaan yang sangat susah didapati dan prospek pekerjaan yang semakin berkurang. Lulusan sarjana dari universitas semakin bertambah yang merupakan itu semua adalah calon pengangguran. Penyebabnya adalah rendahnya ketahanan dan beradaptasinya mahasiswa dalam menghadapi perkembangan zaman tidaklah terikuti (Salleh Amat, Mhd Subhan, Wan Marzuki Wan Jaafar, Zuria Mahmud \& Ku Suhaila Ku Ali@ Ku Johari, 2014;241). Ditambah lagi ramai mahasiswa yang masih rendah pengetahuan, informasi pekerjaan tidak banyak didapatkan, arah cita-cita tidak jelas, perancangan karir, dan penyelesaian masalah tidaklah bisa terselesaikan. Hal ini lah mahasiswa menjadi galau atau kacau ketidak keruan dalam menghadapi perkembangan zaman ini. Mahasiswa menjadi bingung dalam menentukan pekerjaan yang sesuai dengan minat bakatnya sendiri dan mahasiswa menjadi bermalas-malasan serta banyak bermain untuk mencari kebahagiaan dalam kehidupannya. Seharusnya universitas telah memikirkan bagaimana lulusan calon alumninya menjadi cemerlang dan bagus kematangan karir selepas tamat daripada universitas. Apalagi, konselor di universitas masih banyak belum ada unit atau bidang konselor di universitas yang bisa membantu masalah-masalah mahasiswa terutama masalah sikap dan keterampilan mahasiswa yang ada di universitas. 


\section{Empati Remaja Terhadap Korban Bullying Di Pekanbaru}

Pada dasarnya secara teori (Super, 1957), menjelaskan bahwa tugas perkembangan mahasiswa terletak pada umur 18 tahun hingga 25 tahun yang merupakan tahap eksplorasi yang memerlukan banyak menggali keterampilan-keterampila dan juga dapat membentuk sikap sopan santunya mahasiswa semasa kuliah di universitas. Pada masa umur 18 hingga 25 tahun ini mahasiswa telah memulai merancang dan memilih pekerjaan supaya semasa tamat kuliah nanti dari universitas tidak menjadi tamatan sarjana yang berstatus pengangguran (Yowell, Andrews \& Buzzetta 2011; Mhd Subhan, Mas'ud Zein, Akhyar, Mohd Hakimie Zainal Abidin, Sallehudin Ali, Salleh Amat, Mohd Izwan Mahmud, Aida Hanim A. Hamid \& Abu Yazid Abu Bakar, 2018). Pada peringkat percobaan atau eksplorasi ini mahasiswa telah mulai untuk merancang dan menentukan sikap pemilihan karir supaya individu mudah untuk eksplorasi dan memilih pekerjaan yang sesuai dengan keinginannya sendiri sebelum tamat kuliah dari universitas. Tahap kematangan individu merupakan peranan terhadap tingkah laku dalam pengambilan sikap perencanaan karir.

Kasus kemandirian dan ketidakmatangan mahasiswa semakin banyak terlihat didepan semua orang. Seperti ramainya mahasiswa yang melakukan aktivitas-aktivitas yang tidak bermanfaaat, nongkrong di café yang tidak ada hasil yang bermanfaat, budaya membaca dan menulis tidak senangi, faktor game online yang menjadikan sebagai pengalihan kebahagiaan dan masih banyak permasalahan-permasalahan yang didasari oleh ketidakmatangan mahasiswa menghadapi era teknologi ini. Baru-baru ini yang terjadi di media (PikiranRakyat.com) merupakan salah satu berita yang menyampaikan dengan judul Industri 4.0 berpontensi tambah jumlah pengangguran pada Rabu, 16 Oktober 2019. Isi beritanya menyampaikan "Penerapan industri 4.0 berpotensi menyebabkan 600 juta orang di dunia kehilangan pekerjaannya". Informasi ini menjadi sangat membahayakan bagi seluruh mahasiswa yang akan tamat kuliah dari universitas. Menurut Chi, Leuty, Bullock Yowell \& Dahlen (2018) didapati rendahnya kematangan karir mahasiswa yang memberi dampak negatif terhadap emosional dan prestasi mahasiswa. Sikap mahasiswa menjadi tidak memliki keranian dan rendah kepercayaan dirinya untuk menggapai sesuatu yang diinginkannya. Sedangkan dampak terhadap prestasi mahasiswa seperti nilai IPK nya yang rendah. Dengan demikian isu kematangan karir ini memiliki dampak yang serius untuk dilaksanakan penelitian. Supaya dapat memberikan solusi kepada mahasiswa yang memiliki rendah kematangan karirnya.

Ditelusuri penyebab rendahnya kematangan karirnya adalah pengetahuan dan pemahaman mahasiswa yang masih rendah, kurangnya mengetahui bakat dan minatnya sendiri, kesiapan kerja yang masih belum siap, rendahnya berkompromi dengan masa depannya dan kurangnya keyakinan yang ada dalam dirinya. Hal ini terjadi karena faktor kemajuan teknologi dan mudahnya akses internet yang memberi dampak terhadap mahasiswa yang kurang mencari informasi dan perancangan karir tentang pekerjaan untuk di masa depannya. Jika selalu dibiarkan hal ini terjadi kepada mahasiswa yang akan tamat kuliah daripada Universitas maka akan menimbulkan ramainya calon pengangguran selepas tamat pengajian. Dengan demikian, penelitian ini perlu dilakukan terhadap mahasiswa prodi ekonomi yang akan tamat kuliah daripada universitas. Mahasiswa prodi ekonomi dijadikan responden dalam penelitian disebabkan karena hasil pengamatan penulis bahwa ramai mahasiswa prodi ekonomi yang masih kebingungan dalam menentukan pilihan karirnya untuk masa depan. Asumsi awal penelitian ini adalah mahasiswa yang memiliki kematangan karir akan mempermudah bagi mahasiswa untuk mencapai kecemerlangan dan kebahagiaan di masa depan. Berdasarkan hasil observasi dilapangan maka peneliti merasa penting melakukan penelitian dengan judul "Kematangan Karir Mahasiswa Prodi Ekonomi Dalam Pemilihan Karir".

\section{METODE PENELITIAN}

Teknik penelitian menggunakan pendekatan kuantitatif yang memberikan gambaran tentang kematangan karir mahasiswa prodi ekonomi dalam pemilihan karir dan melihat perbedaan 
kematangan karir mahasiswa prodi ekonomi dalam pemilihan karir. Metode deskriptif ini sesuai untuk dilaksanakan penelitian yang mendapatkan hasil gambaran yang memuaskan (Cresswell, 2017). Lokasi penelitian ini bertempayt di Universitas Islam Negeri Sulthan Syarif Kasim Riau. Sampel penelitian terdiri 50 orang mahasiswa yang menggunakan teknik persampelan simpel random sampling. Alat pengumpulan data penelitian ini menggunakan instrumen kematangan karir yang memiliki 2 domain yaitu domain sikap yang memiliki 25 item dan domain kompetensi memiliki 25 item juga yang menggunakan skor. Analisis data penelitian menggunakan skor yaitu skor 1 hingga 25 memiliki interpretasi kematangan karir yang rendah dan skor 26 hingga 50 memiliki interpretasi kematangan karir yang tinggi (Crites, 1978). Manakala analisis data untuk perbedaan antara jenis kelamin laki-laki dan perempuan menggunakan analisis independent t-test. Syarat melaksanakan analisis parametrik telah dilaksanakan dengan menggunakan ujian homogenitas yang di analisis dengan statistik levene's test yaitu $\mathrm{p}=0.734>0.05$ dan ujian normalitas menggunakan statistik skewness $=-0.359$ dan kurtosis $=-0.415$ yang menunjukkan data berdistribusi normal. Hal ini disokong oleh (Tabachnick \& Fidell, 2013) menjelaskan apabila nilai -2 hingga +2 maka data tersebut menunjukkan berdistribusi normal.

\section{HASIL}

Penelitian ini menunjukkan gambaran kematangan karir mahasiswa prodi ekonomi dalam pemilihan karir yang dapat dilihat sebagai berikut:

Tabel 1. Deskriptif Kematangan Karir Mahasiswa Prodi Ekonomi

\begin{tabular}{cccc}
\hline Data Interval & Interpretasi & F & \% \\
\hline $\mathbf{1 - 2 5}$ & Rendah Kematangan Karir & 28 & $\mathbf{5 6 \%}$ \\
$\mathbf{2 6 - 5 0}$ & Tinggi Kematangan Karir & 22 & $\mathbf{4 4 \%}$ \\
$\mathbf{N}$ & & $\mathbf{5 0}$ & $\mathbf{1 0 0 \%}$ \\
\hline
\end{tabular}

Berdasarkan analisis data deskriptif bahwa mahasiswa prodi ekonomi menunjukkan 28 mahasiswa yang memiliki rendah kematangan karir yang didapati 56\%. Manakala 22 mahasiswa memiliki tinggi kematangan karir yang didapati 44\%. Dengan demikian, dapat disimpulkan mahasiswa prodi ekonomi memiliki rendah kematangan karir yang disebabkan ramainya yang memiliki skor 1-25 yang menunjukkan kematangan karir mahasiswa prodi ekonomi yang memiliki kategori rendah.

\section{Tabel 2. Perbedaan Kematangan Karir Mahasiswa Prodi Ekonomi Berdasarkan Jenis Kelamin}

\begin{tabular}{llllcrrr}
\hline Independent t-test & Kumpulan & $\mathbf{N}$ & Min & Interpretasi & Nilai t & Sig. (p) & Keputusan \\
\hline Kematangan kerjaya & Laki-Laki & 21 & 22.75 & Rendah & -5.472 & .000 & Ditolak \\
& Perempuan & 29 & 38.63 & Tinggi & & & \\
\hline
\end{tabular}

Signifikan pada aras $\mathrm{p}<0.05$

Berdasarkan analisis data independent t-test maka hasil penelitian ini menunjukkan terdapat perbedaan yang signifikan kematangan karir berdasarkan jenis kelamin mahasiswa prodi ekonomi $(\mathrm{t}=-5.472, \mathrm{p}=.000<0.05)$. Ini menunjukkan bahwa Ho ditolak. Perbedaannya menunjukkan bahwa kematangan karir mahasiswa perempuan lebih tinggi yaitu skor $=38.63$ berbanding dengan kematangan karir mahasiswa laki-laki yaitu skor $=22.75$. 


\section{PEMBAHASAN}

Penelitian ini menunjukkan bahwa ramainya mahasiswa prodi ekonomi yang memiliki kematangan karir yang rendah yaitu memiliki skor 1-25. Hal ini menunjukkan mahasiswa prodi ekonomi sedikit yang memiliki kematangan karir yang tinggi. Maka dengan demikian, mahasiswa prodi ekonomi sangat memerlukan program untuk meningkatkan kematangan karir dalam pemilihan karir. Faktor yang menyebabkan rendahnya kematangan karir mahasiswa disebabkan banyaknya mahasiswa yang rendah pengetahuan dan pemahaman tentang dunia pekerjaan. Lebih banyak pengetahuan dan pemahaman mahasiswa terhadap game online dan banyaknya mahasiswa menggunakan waktunya untuk aktivitas yang tidak bermanfaat seperti nogkrong di cafe.

Sesuai dengan penelitian Ismail, Abdullah, Mohamad \& Khairuldin, (2018) menunjukkan ramainya mahasiswa universitas yang memiliki kategori kematangan karir yang rendah. Hasil penelitiannya menunjukkan faktor yang menyebabkan mahasiswa rendah kematangan karir adalah salah satunya pengetahuan dan pemahaman serta kesiapan mahasiswa terhadap pekerjaan yang akan dipilihnya. Namun, berbeda dengan hasil penelitian Lau, Low \& Zakaria, (2013) yang menyatakan bahwa kematangan karir dalam kalangan mahasiswa memiliki kategori yang tinggi. Mahasiswa telah banyak mendapatkan program perancangan karir yang dilaksanakan oleh unit perkembangan karir dan alumni universitas untuk persediaan calon-calon alumni kampus yang akan tamat kuliah. Dengan demikian, hasil deskriptif kematangan karir mahasiswa prodi ekonomi memberi peranan penting bagi kampus untuk meningkatkan kematangan karir yang memberikan program-program tentang perancangan karir mahasiswa supaya terhindar dari isu pengangguran yang terjadi di era revolusi industri 4.0 yang meminta kesiapan dan kematangan mahasiswa untuk bekerja.

Manakala hasil penelitian perbedaan kematangan karir mahasiswa prodi ekonomi berdasarkan jenis kelamin menunjukkan perbedaan yang signifikan antara mahasiswa perempuan yang memiliki kematangan karir yang tinggi berbanding mahasiswa laki-laki. Berbeda dengan hasil penelitian Mohd Hakimie Zainal Abidin, Salleh Amat, Mhd Subhan, Mohd Izwan Mahmud, Sallehuddin Ali, Abu Yazid Abu Bakar, (2018) yang menunjukkan kematangan karir antara mahasiswa laki-laki dan perempuan memiliki kategori tinggi. Begitu juga menurut Lau, Low \& Zakaria, (2013) menyatakan jenis kelamin laki-laki memiliki kematangan karir yang tinggi berbanding dengan jenis kelamin perempuan. Dengan demikian, tidak selalu jenis kelamin perempuan menunjukkan kematangan karirnya berkategori tinggi. Namun, bisa terjadi juga mahasiswa laki-laki yang lebih tinggi kematangan karir berbanding perempuan dan bisa terjadi juga sama-sama tinggi kematangan karirnya.

\section{SIMPULAN}

Penelitian ini dapat disimpulkan bahwa penelitian kematangan karir mahasiswa prodi ekonomi dalam pemilihan karir, memiliki kemanfaatan bagi seluruh stake holder yang berkaitan tentang meningkatkan kematangan karir dalam kalangan mahasiswa di Universitas. Supaya dapat bersama-sama untuk melakukan program-program atau kegiatan yang dapat meningkatkan kematangan karir mahasiswa kearah yang lebih baik. Begitu juga, Unit perkembangan karir mahasiswa dan alumni di Universitas perlu dibentuk supaya dapat menjalankan program-program karir yang mengembangkan mahasiswa menjadi alumni yang berprestasi dan tidak menjadi alumni yang pengangguran selepas tamat kuliah.

\section{REFERENSI}

Chi, J., Leuty, M. E., Bullock-Yowell, E., \& Dahlen, E. R. 2018. Work Value Differentiation and Profile Elevation: What Do They Predict? Journal of Career Assessment. . https://doi.org/10.1177/1069072718813368. 
Crites, J.O. 1978. Career maturity inventory : Theory and research bandbook.California : CTB/McGraw Hill.

Creswell, J. W. 2017. Research Design: Pendekatan metode kualitatif, kuantitatif, dan campuran edisi 4 terjemahan. Yogyakarta: Pustaka pelajar.

Ismail, M. S., Abdullah, S. S., Mohamad, M. Z., \& Khairuldin, W. M. K. F. W. 2018. Student's Career Maturity: Implications on Career Counselling. International Journal of Academic Research in Business and Social Sciences, 8(4), 887-897.

Lau, P. L., Low, S. F., \& Zakaria, A. R. 2013. Gender and work: Assessment and application of Super's theory career maturity. Journal Psychology and Behavioral Sciences, $2: 36-42$.

Mhd Subhan, Mas'ud Zein, Akhyar, Mohd Hakimie Zainal Abidin, Sallehudin Ali, Salleh Amat, Mohd Izwan Mahmud, Aida Hanim A. Hamid \& Abu Yazid Abu Bakar. 2018. Reliability of self-employment intentions instrument among international students in Indonesian university. International Journal of Engineering and Technology $(U A E), 7(2)$, 7679. https://doi.org/10.14419/ijet.v7i2.10.10960.

Mohd Hakimie Zainal Abidin, Salleh Amat, Mhd Subhan, Mohd Izwan Mahmud, Sallehuddin Ali, Abu Yazid Abu Bakar. 2018. Career maturity among gifted and talented students in Malaysia. International Journal of Engineering and Technology(UAE), 7(2), 74-75.

Salleh Amat, Mhd Subhan, Wan Marzuki Wan Jaafar, Zuria Mahmud \& Ku Suhaila Ku Ali@ Ku Johari. 2014. Evaluation and psychometric status of the brief resilience scale in a sample of Malaysian international students. Asian Social Science, 10(18), 240245. https://doi.org/10.5539/ass.v10n18p240.

Super, D.E. 1957. The psychology of career: An introduction to vocational development. New York, NY: Harper \& Row Publisher. Career Information, Career Counselling \& Career Development. $7^{\text {th }}$, Ed. Boston: Allyn and Bacon.

Tabachnick, B. G., \& Fidell, L. S. 2013. Using Multivariate Statistics, 6th Edition.

PilihanRakyat.com. Diakses pada 16 Oktober 2019.

Yowell, B., Andrews, \& Buzzetta. 2011. Explaining career decision making self-efficacy: Personality, cognitions, and cultural mistrust. The Career Development Quarterly, 5 : 400-411. 